\title{
Treatment of Hairy Urethra with Holmium: YAG Laser Ablation: A Case Report
}

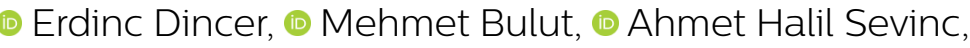 \\ (ㄱ) Burcu Hancl Sevinc, (1) Fatih Tarhan
}

\author{
Department of Urology, University \\ of Health Sciences, Kartal Dr. Lütf \\ Kırdar Training and Research \\ Hospital, İstanbul, Turkey \\ Submitted: 28.04 .2020 \\ Accepted: 29.05.2020 \\ Correspondence: Erdinc Dincer, \\ SBÜ Kartal Dr. Lütfi Kırdar Eğitim \\ ve Araştırma Hastanesi, Üroloji \\ Anabilim Dalı, İstanbul, Turkey \\ E-mail: drerdincdincer@gmail.com

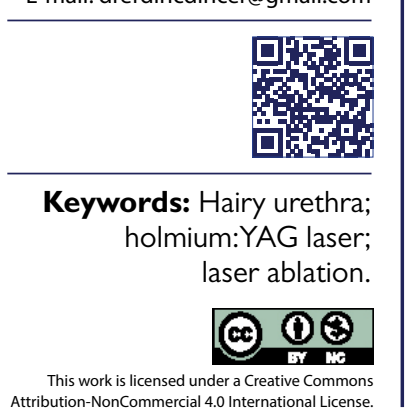

\begin{abstract}
The presence of hair in the urethra can lead to recurrent, uncomfortable complications following various operations. A 76 years old male patient who admitted with voiding difficulty underwent internal urethrotomy and laser ablation treatment for hairy urethra. The case is presented and discussed with the relevant literature.
\end{abstract}

\section{INTRODUCTION}

The urethra does not contain any hair follicles, and therefore, normally, no hair is present. However, a hairy urethra can occur following procedures such as hypospadias surgery, urethroplasty with penile and scrotal skin, and female to male transgender surgery. In the literature, there is insufficient data about the incidence of this complication. Rogers et al. ${ }^{[1]}$ reported an incidence of $5 \%$ in a series with 194 patients. Intense hair growth in the new urethra can lead to recurrent bothersome complications. ${ }^{[2,3]}$

This report describes the case of a 76-year-old male patient with urethral hair after having undergone scrotal graft urethroplasty and the subsequent treatment with urethroscopic holmium:YAG (Ho:YAG) laser ablation.

\section{CASE REPORT}

A 76-year-old male presented with dysuria and a weak urinary stream. He had undergone urethroplasty with a scrotal dermal graft 5 years earlier as a result of two transurethral resections of the prostate. The patient also had a history of internal urethrotomy 4 years prior, following the urethroplasty. A physical examination revealed scarring of the ventro-lateral penile and perineal skin due to the previous surgeries. Uroflowmetry showed a Qmax of $5 \mathrm{~mL} /$ second and a retrograde urethrogram revealed a stricture. Under spinal anesthesia in the dorsal lithotomy position, cystouretroscopy was performed. Hair follicles and an annular stricture were detected in the membranous urethra (Fig. Ia). After passing a guidewire proximal to the stricture, the stricture was cut at the 12 o'clock position under direct vision. The sphincter, prostate, bladder neck, and bladder were endoscopically normal. Following the internal urethrotomy, the hairs were pulled taut with a grasper and a 400-micron Ho:YAG laser fiber delivered through the ureteral catheter was applied to the hair roots with I J and $8 \mathrm{~Hz}$. The ablation was successful (Fig. Ib) and the hairs were removed with a grasper (Fig. Ic). The patient was discharged on the postoperative first day and a Foley catheter was removed after I week. No postoperative complications were seen at a I-month follow-up visit. A 3-month control cystourethroscopy was scheduled. Written, informed consent was obtained from the patient.

\section{DISCUSSION}

Abnormal hair in the urethral skin tissue can cause a variety of problems, such as urinary tract infection, urethral 

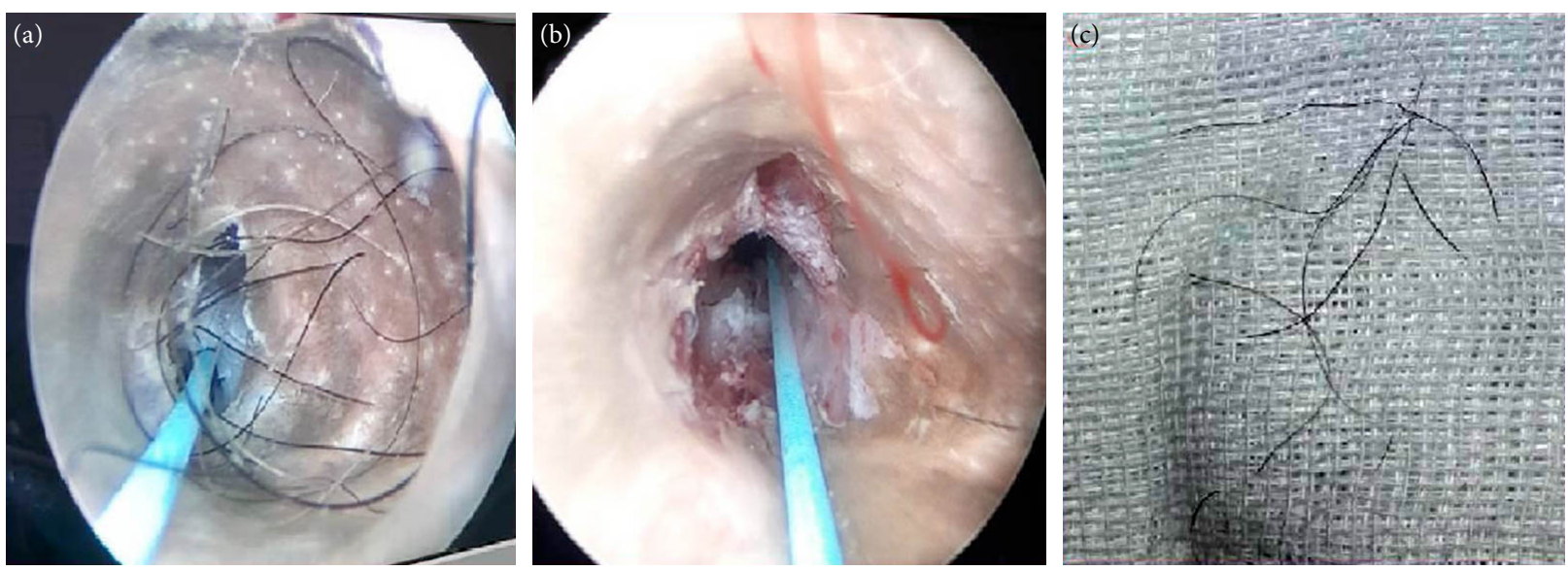

Figure 1. (a) Preoperative imaging of the hairy urethra; (b) Postoperative imaging of the urethra; (c) Hairs removed from the urethra.

calculi, or re-stenosis. ${ }^{[2,3]}$ Patients generally present with complaints of dysuria, hematuria, and difficulty urinating and sometimes hair growth while urinating. The diagnosis is established endoscopically.

In order to prevent the formation of hair in the urethra, it is appropriate to prefer hairless tissues such as buccal mucosa, post-auricular skin, and foreskin. When this cannot be avoided, superficial local radiotherapy, external or direct thermo-coagulation and laser epilation ${ }^{[4]}$ of the hair follicles can be applied to the donor site prior to surgery. However, it may not be possible to create a completely hairless neo-urethra. A reduction of $80 \%$ is an accepted result. ${ }^{[4]}$ If prevention fails, treatment of urethral hair formation is required. Electrocauterization ${ }^{[2]}$ application of intraurethral depilatory cream containing thioglycolic acid, $^{[3,5]}$ and laser epilation ${ }^{[2,3,6-8]}$ are methods that can be applied. Successful laser treatment results have been reported with carbon dioxide, ${ }^{[7]}$ diode, ${ }^{[2]}$ neodymium:YAG (Nd:YAG), ${ }^{[2,3,6,8]}$ and Ho:YAG ${ }^{[9,10]}$ lasers. The first such use of a laser was performed by Finkelstein et al. ${ }^{[6]}$ using Nd:YAG. Treatment of urethral hair using a Ho:YAG laser was first described in 2011. ${ }^{[9]}$ However, repeated laser applications of 2 to 4 times with 3-month intervals may be necessary. ${ }^{[2,6-8]}$ Recurrent intraurethral thioglycolic acid administration as an adjuvant to laser therapy may contribute to reducing the number of interventions and increasing success.

A Ho:YAG laser has a wavelength of $2120 \mathrm{~nm}$ and penetration depth of $0.4 \mathrm{~mm}$. Potential disadvantages of Ho:YAG laser treatment in the urethra include the possibility of fever, urinary tract infection, fibrosis, stenosis, and hair regrowth. We preferred this minimally invasive approach because the urologists were familiar with the use of a laser in the urethra and success is more likely if the laser beats are closer to the root of the hair follicle.

Ho:YAG laser epilation is a feasible alternative treatment modality for urethral hair after urethroplasty that is both easy to be perform and minimally invasive. Although the long-term results of our case are not known, other cases in the literature have presented long-term success.
Acknowledgement

None.

Informed Consent

Written informed consent was obtained from the patient for the publication of the case report and the accompanying images.

Peer-review

Internally peer-reviewed.

Authorship Contributions

Concept: E.D., F.T.; Design: E.D., A.H.S.; Supervision: F.T.; Data: E.D., M.B.; Literature search: E.D., A.H.S., B.H.S., F.T.; Writing: E.D., F.T.; Critical revision: E.D., B.H.S., F.T.

Conflict of Interest

None declared.

\section{REFERENCES}

1. Rogers HS, Mc Nicholas TA, Blandy JP. Long-term results of onestage scrotal patch urethroplasty. Br J Urol 1992;69:621-8.

2. Neal DE Jr, Orihuela E, Crotty K, LaHaye M, Davidson S, Motamedi M. Laser ablation of urethral hair. Lasers Surg Med 1999;24:261-3.

3. Singh I, Hemal AK. Recurrent urethral hair ball and stone in a hypospadiac: management and prevention. J Endourol 2001;15:645-7.

4. Pigot GLS, Belboukhaddaoui S, Bouman MB, Meuleman EJH, de Boer EM, Buncamper ME, et al. Effectiveness of Preoperative Depilation of the Urethral Donor Site for Phalloplasty: Neourethral Hair Growth and its Effects on Voiding. Eur Urol Focus 2020;6:770-5.

5. Kukreja RA, Desai RM, Sabnis RB, Patel SH, Desai MR. The urethral instillation of depilatory cream for hair removal after scrotal flap urethroplasty. BJU Int 2001;87:708-9.

6. Finkelstein LH, Blatstein LM. Epilation of hair-bearing urethral grafts using the neodymium: YAG surgical laser. J Urol 1991;146:840-2.

7. Cohen S, Livne PM, Ad-El D, Lapidoth M. CO2 laser desiccation of urethral hair post-penoscrotal hypospadias repair. J Cosmet Laser Ther 2007;9:241-3.

8. Crain DS, Miller OF, Smith L, Roberts JL, Ross EV. Transcutaneous laser hair ablation for management of intraurethral hair after hypospadias repair: initial experience. J Urol 2003;170:1948-9.

9. Beiko D, Pierre SA, Leonard MP. Urethroscopic holmium:YAG laser epilation of urethral diverticular hair follicles following hypospadias 
repair. J Pediatr Urol 2011;7:231-2.

10. Sancı A, Gülpınar B, Gülpınar Ö. Successful management of hair fol- licles following urethroplasty with holmium:YAG laser epilation: A case report. J Surg Med 2019;3:817-9.

Holmium YAG laser ablasyon ile kıllı üretranın tedavisi: Olgu Sunumu

Üretrada kıl varlığı çeşitli operasyonlardan sonra ortaya çıkabilir ve tekrarlayan rahatsız edici komplikasyonlara yol açabilir. İşeme zorluğu ile başvuran 76 yaşında erkek hastaya kıllı üretra için internal üretrotomi ve lazer ablasyon tedavisi uygulandı. Olgu ilgili literatür eşliğinde sunulmuş ve tartışılmışırır.

Anahtar Sözcükler: Holmium yag lazer; Kıllı üretra; lazer ablasyon. 